\title{
Bone marrow cytological evaluation in dogs with chronic kidney disease
}

\author{
[Avaliação citológica da medula óssea de cães com doença renal crônica] \\ S. Borin-Crivellenti ${ }^{1}$, L.Z. Crivellenti ${ }^{1}$, M.B. Carvalho ${ }^{2}$, A.E. Santana ${ }^{2}$ \\ ${ }^{1}$ Aluno de pós-graduação em Medicina Veterinária- Universidade Estadual Paulista -Unesp - Jaboticabal, SP \\ ${ }^{2}$ Universidade Estadual Paulista - Unesp - Jaboticabal, SP
}

\begin{abstract}
Since anemia is indicated as an important compromising factor for the quality of life of dogs with chronic kidney disease (CKD), bone marrow cytological analysis may provide more information on the hematological profile these dogs and, therefore, allow clinicians to not only choose the most adequate treatment but also monitor the response to therapy. The aim of this study was to investigate the feasibility with sternal bone marrow puncture in chronic kidney disease (CKD) using only local anesthesia and check if the cytological analysis is helpful to determine the hematological status. We found that erythroid hypoplasia occurred only in terminal CKD patients, and that the bone marrows of dogs with CKD stages 2 and 3 were quantitatively similar to those of elderly dogs. All dogs tolerated the bone marrow puncture using only local anesthesia with lidocaine and bone marrow cytological evaluation may be a useful tool for hematopoietic evaluation of anemic dogs with CKD.
\end{abstract}

Keywords: dog, anemia, myelogram, erythropoiesis, renal failure

\section{RESUMO}

Sendo a anemia apontada como um importante fator comprometedor da qualidade de vida dos cães portadores de doença renal crônica (DRC), a análise citológica da medula óssea poderia fornecer mais informações acerca do perfil hematológico desses animais e, portanto, possibilitar ao clínico não somente optar por um tratamento mais adequado, mas também monitorar a resposta à terapia. Diante disso, objetivou-se com este estudo avaliar a praticabilidade e a aceitação do procedimento de coleta de medula óssea do osso esterno de cães com doença renal crônica (DRC) utilizando somente anestesia local, bem como verificar se os resultados fornecidos na análise citológica fazem-se úteis à composição do quadro hematológico desses pacientes. Observou-se que a manifestação de hipoplasia da série eritroide só ocorreu nos pacientes em estádio terminal da DRC, e que as medulas ósseas dos DRC em estádio 2 e 3 assemelharam-se quantitativamente à medula de animais idosos. Os cães de todos dos grupos toleraram bem a punção do osso esterno somente com uso de lidocaína, podendo ser esta, portanto, uma ferramenta útil na complementação da abordagem hematopoiética de cães anêmicos com DRC.

Palavras-chave: cão, anemia, mielograma, eritropoiese, insuficiência renal

\section{INTRODUCTION}

Anemia is an early event in the course of chronic kidney disease (CKD) and is a universal finding in the advanced stages of the disease. Normocytic, normochromic, nonregenerative anemia results primarily from impaired ability of the kidneys to produce a sufficient amount of

Recebido em 5 de junho de 2014

Aceito em 11 de novembro de 2014

E-mail: sofiaborincrivellenti@yahoo.com.br erythropoietin; however, iatrogenic and spontaneous blood loss, poor nutrition, and reduced red blood cell lifespan may also contribute to it (Polzin, 2011).

Little information on bone marrow evaluation in dogs with CKD is available even in cases of chronic anemia. Even though bone marrow biopsy is desirable in chronic cases, it usually 
requires general anesthesia, which is not recommended in ASA 4 patients (American Society of Anesthesiologist - patients with severe systemic disease that is a constant threat to life) (Fleisher, 2005). An alternative to this procedure is cytological evaluation of bone marrow samples obtained from the epiphysis of long bones or regions of the ileum, such as the iliac crest or acetabular rim (Riley et al. 2004). However, sedation or anesthesia is still required even though it is not difficult to execute nor causes major complications (Miller and Lunn, 2007).

Sternal puncture under local anesthesia has been routinely used to obtain bone marrow samples for cytological evaluation in human medicine since its description by Arinkin in 1927 (Osgood and Seaman, 1944). The sternum has historically not been aspirated in animals because of concerns regarding thoracic penetration (Moritz et al., 1993). However, the sternum has less soft tissue coverage than the ilium, femur, or humeral head, and the thinner cortex is readily accessible (Guillot et al., 2011). A recent research showed that aspiration of sternal bone marrow with hypodermic needles was feasible and safe in small dogs under anesthesia, and samples equivalent in quality to those from the humerus or ilium can be obtained from clinically normal dogs (Defarges et al., 2003).

The purpose of this study was to assess the feasibility and patient response to sternal bone marrow puncture in dogs with CKD using only local anesthesia and, additionally, to check if the cytological analysis data obtained are helpful to determine the hematological status of these patients.

\section{MATERIAL AND METHOD}

The animals included in this study were clientowned and consisted of eight healthy dogs and twenty-four dogs with chronic kidney disease. This study was approved by the Veterinary Ethics Committee of UNESP - Univ Estadual Paulista, campus Jaboticabal, São Paulo, Brazil (nº06137-09).

The age of the elderly healthy dogs (2 female and 6 male mongrel dogs) ranged from 6 to 12 years (mean $9 \pm 4.24$ years) and their weight ranged from 6.8 to $27.6 \mathrm{~kg}$ (mean $16.16 \pm 7.03 \mathrm{~kg}$ ).
The CKD dogs included in this study were distributed into three groups: CKD stage 2 (CKD 2), CKD stage 3 (CKD 3 ) and CKD stage 4 (CKD 4) (IRIS, 2009). The CKD 2 group comprised 4 female and 4 male dogs, which ranged from 8 to 15 years in age (mean $11.5 \pm 4.95$ years) and weighed from 2.75 to $25.2 \mathrm{~kg}$ (mean $11.33 \pm 7.95 \mathrm{~kg}$ ). CKD 3 comprised 4 females and 4 males, which ranged from 5 to 15 years in age (mean 9.4 \pm 3.41 years) and weighed 3.5 to $52.0 \mathrm{~kg}$ (mean $21.5 \pm 18.16 \mathrm{~kg}$ ). CKD 4 comprised 3 females and 5 males, which ranged from 4 to 14 years in age (mean 9.5 \pm 4.51 years) and weighed 5.65 to $43.0 \mathrm{~kg}$ (mean $21.09 \pm 14.20 \mathrm{~kg}$ ). The breeds represented in all CKD groups were Poodle ( $n=$ five), Cocker spaniel ( $n=$ two), Weimaraner ( $n=$ one), Labrador retriever ( $n=0 n e)$, Fox terrier $(n=0 n e)$, Saint Bernard ( $n=0 n e)$, Chow Chow ( $n=$ one), Shih Tzu ( $n=0 n e)$, Boxer ( $n=0 n e)$ and Maltese $(n=o n e)$; the nine remaining dogs were mixed-breed. The criteria for selection of CKD patients included a clinical course of over 90 days, and serum creatinine concentration above $1.4 \mathrm{mg} / \mathrm{dL}$ in hydrated patients, as assessed in three different moments over the course of a few weeks, as per IRIS guidelines (2009). Patient exclusion criteria for all groups included blood transfusion or treatment with drugs that stimulate hematopoiesis (nandrolone, rhG-CSF, thymomodulin and/or erythropoietin), and dogs with neoplasms, inflammatory conditions or other comorbidities.

Peripheral blood samples were obtained for erythrogram and biochemical analyses relevant to the staging of CKD and ensure suitable health in the control dogs. All dogs were restrained in a sitting position to improve palpation and visualization of the sternum (Guillot et al., 2011) (Figure 1A), and were systematically submitted to clipping and the skin antisepsis was performed with alcohol $70 \%$. Local anesthesia with $0.2 \%$ lidocaine was performed in the skin and periosteum (Figure 1B). The needle was inserted into the cortex of the centre of thefi rst sternebra (Figure 1C) and advanced until firmly embedded. A small volume of bone marrow $(0.5 \mathrm{~mL})$ was harvested from the sternal manubrium using an 18 to 21-gauge sterile hypodermic needle attached to a $10 \mathrm{~mL}$ syringe containing sterile EDTA by applying negative pressure (Figure 1D). Local hemostasis was achieved by applying direct pressure. The researcher in charge of 
cytological assessment was blinded to the case history and previous cytological evaluation results. A 500-cell differential count was performed on each of 2 bone marrow aspirations smears. The assessment of cell types in the differential count was performed. The percentages of myeloid (M) and erythroid (E) cells were determined and the $\mathrm{M}: \mathrm{E}$ ratio were calculated (Jain, 1993).

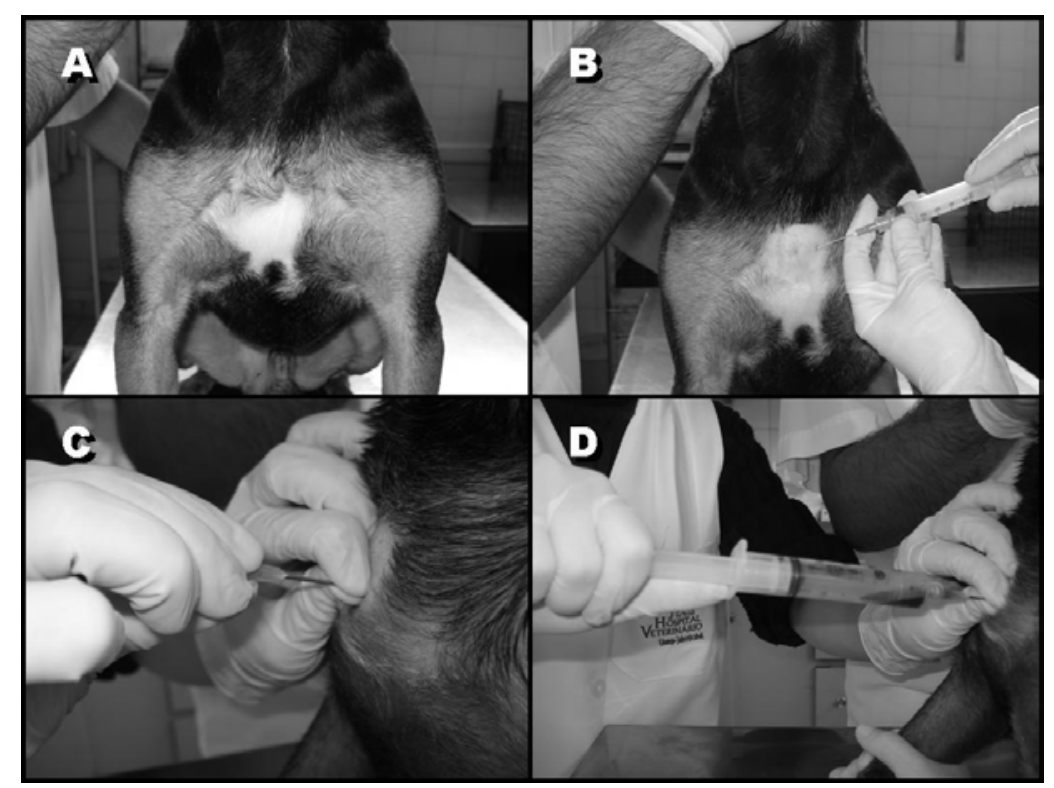

Figure 1. Canine sternal bone marrow harvest procedure. (1A) Sternal sitting position to improve palpation and visualization of the sternum and perform aspiration. (1B) Local anesthesia of the skin and periosteum with $0.2 \%$ lidocaine. (1C) Insertion of the needle into the cortex of the center of thefirst sternebrae. (1D) Bone marrow collection from the sternal manubrium using an $18 \mathrm{G}$ sterile hypodermic needle attached to a $10 \mathrm{~mL}$ syringe containing EDTA by applying negative pressure.

Data were analyzed with statistical analysis software (GraphPad Prism 4). The means from each group were compared with the one-way analysis of variance or test of Kruskal-Wallis anova on Ranks, according to the test of normality by Kolmogorov-Smirnov for the values that had no Gaussian distribution. In addition, the means were evaluated by Tukey Test when the values of $P$ were lower or equal to 0.05 and were considered significant. Pearson's correlation coefficient was used to analyze the relationship between the hematological variables and erythroid precursors, and M:E ratio.

\section{RESULTS}

The current study should validate sternal technique in aged and sick patients of different sizes and various breeds under local anesthesia with lidocaine. Twitching, growling and whining were the only reactions observed during bone marrow aspiration (12.5\%, 2.43\% and 4.87\%, respectively).

In three cases a second puncture was necessary owing to needle clogging with bone fragments during bone marrow suction, which resulted in a first attempt success rate of $92.5 \%$.

No hematological changes, signs of perforation of the anterior thoracic cavity, infection or bruises on the sampling sites were observed in follow-up appointments.

Urinary parameters, serum biochemistry, and blood pressure values used for evaluation of the control group and classification of CKD into the respective subgroups (IRIS, 2009) are shown in Table 1. Blood and bone marrow characteristics of both control and CKD groups are presented in Table 2. 
Table 1. Urinary parameters, serum biochemistry, and blood pressure values (mean \pm SD) used for evaluation of dogs from the control group (CG), and dogs with chronic kidney disease (CKD) stage 2 (CKD2), stage 3 (CKD3), and stage 4 (CKD4)

\begin{tabular}{|c|c|c|c|c|}
\hline & CG & CKD2 & CKD3 & CKD4 \\
\hline \multicolumn{5}{|l|}{ Serum biochemistry } \\
\hline Creatinine (mg/dL) & $1.04 \pm 0.11 \mathrm{a}$ & $1.75 \pm 0.18 b$ & $3.45 \pm 0.38 b$ & $7.33 \pm 2.58 \mathrm{c}$ \\
\hline Urea (mg/dL) & $29.93 \pm 10.22 \mathrm{a}$ & $93.61 \pm 26.80 \mathrm{~b}$ & $154.30 \pm 33.77 \mathrm{c}$ & $233.70 \pm 62.59 d$ \\
\hline Phosphate (mg/dL) & $4.40 \pm 0.57 \mathrm{a}$ & $4.52 \pm 1.04 \mathrm{a}$ & $6.39 \pm 2.12 \mathrm{ab}$ & $9.64 \pm 6.44 \mathrm{~b}$ \\
\hline Total protein (mg/dL) & $7.13 \pm 0.51 \mathrm{a}$ & $7.55 \pm 2.67 \mathrm{a}$ & $6.18 \pm 0.48 \mathrm{a}$ & $6.47 \pm 0.58 \mathrm{a}$ \\
\hline Albumin (mg/dL) & $3.01 \pm 0.26 \mathrm{a}$ & $2.53 \pm 0.23 \mathrm{a}$ & $2.52 \pm 0.52 \mathrm{a}$ & $2.66 \pm 0.43 \mathrm{a}$ \\
\hline \multicolumn{5}{|l|}{ Urinary parameters } \\
\hline Urinary density & $1.041 \pm 0.008 \mathrm{a}$ & $1.018 \pm 0,002 b$ & $1.013 \pm 0.003 \mathrm{~b}$ & $1.011 \pm 0.002 \mathrm{~b}$ \\
\hline UPC & $0.07 \pm 0.03 \mathrm{a}$ & $0.91 \pm 0.81 \mathrm{ab}$ & $1.39 \pm 1.34 \mathrm{~b}$ & $1.39 \pm 0.75 b$ \\
\hline $\begin{array}{l}\text { Systolic Blood } \\
\text { Pressure (mmHg) }\end{array}$ & $132.3 \pm 2.46 a$ & $173.3 \pm 4.17 \mathrm{~b}$ & $187.5 \pm 8.73 b$ & $195.5 \pm 9.32 \mathrm{~b}$ \\
\hline
\end{tabular}

Mean values followed by different superscript letters in the same row are statistically different by Tukey's test $(P<0.05)$. UPC, urine protein:creatinine ratio.

Table 2. Erythrogram and bone marrow characteristics (mean \pm SD) evaluated from dogs from the control group (CG) and respective subgroups of chronic kidney disease (CKD); CKD stage 2, CKD stage 3, and CKD stage 4

\begin{tabular}{|c|c|c|c|c|}
\hline & CG & CKD2 & CKD3 & CKD4 \\
\hline \multicolumn{5}{|l|}{ Erythrogram } \\
\hline HCT (\%) & $50.48 \pm 4.36 a$ & $40.99 \pm 7.80 \mathrm{~b}$ & $33.74 \pm 5.88 \mathrm{bc}$ & $28.87 \pm 5.83 c$ \\
\hline RBC count $\left(\times 10^{6} / \mu \mathrm{l}\right)$ & $7.27 \pm 0.67 \mathrm{a}$ & $5.99 \pm 1.14 \mathrm{~b}$ & $4.87 \pm 1.00 \mathrm{bc}$ & $4.16 \pm 1.01 \mathrm{c}$ \\
\hline $\begin{array}{l}\text { Hemoglobin concentration } \\
\text { (mg/dl) }\end{array}$ & 16.251.98a & $13.03 \pm 2.45 b$ & $10.89 \pm 1.57 \mathrm{bc}$ & $9.11 \pm 1.77 \mathrm{c}$ \\
\hline MCV & $69.49 \pm 3.02 \mathrm{a}$ & $68.41 \pm 3.71 \mathrm{a}$ & $69.47 \pm 3.92 \mathrm{a}$ & $69.88 \pm 3.97 a$ \\
\hline MCHC & $32.10 \pm 1.40 \mathrm{a}$ & $31.79 \pm 1.17 \mathrm{a}$ & $32.41 \pm 1.35 \mathrm{a}$ & $31.62 \pm 1.08 \mathrm{a}$ \\
\hline \multicolumn{5}{|l|}{ Bone marrow analysis } \\
\hline Cellularity & $\begin{array}{l}\text { Normal to } \\
\text { mildly } \\
\text { hypocellular }\end{array}$ & $\begin{array}{c}\text { Mildly } \\
\text { hypocellular }\end{array}$ & $\begin{array}{l}\text { Moderately } \\
\text { hypocellular }\end{array}$ & $\begin{array}{c}\text { Severely } \\
\text { hypocellular }\end{array}$ \\
\hline Cell morphology & Normal & Normal & Normal & Normal \\
\hline Myeloid cell count (\%) & $55.10 \pm 3.97 a$ & $61.55 \pm 6.46 \mathrm{a}$ & $55.53 \pm 9.18 \mathrm{ab}$ & $73.30 \pm 8.24 c$ \\
\hline Erythroid cell count (\%) & $42.04 \pm 4.86 \mathrm{a}$ & $34.95 \pm 5.90 \mathrm{ab}$ & $39.84 \pm 9.48 \mathrm{ab}$ & $31.34 \pm 6.18 b$ \\
\hline M:E ratio & $1.29 \pm 0.30 \mathrm{a}$ & $1.83 \pm 0.49 \mathrm{a}$ & $1.50 \pm 0.55 \mathrm{a}$ & $2.41 \pm 0.47 \mathrm{~b}$ \\
\hline
\end{tabular}

Mean values followed by different superscript letters in the same row are statistically different by Tukey's test $(P<0.05)$. HCT, hematocrit; RBC, red blood cell; MCV, mean corpuscular volume; MCHC, mean corpuscular hemoglobin concentration.

It was observed that only $37.5 \%$ of animals from the control group did not exhibited a normocellular bone marrow. There was a predominance of hypocellular bone marrow in all CKD groups (83.3\%). Hypocellularity was mild in $62.5 \%$ of the dogs from CKD2 and control group, moderate in $37.5 \%$ dogs in CKD3 and severe in $62.5 \%$ dogs in CKD4.

Eighty percent of the dogs with stage 2 CKD did not exhibit anemia, and their response was predominantly regenerative based on absolute reticulocyte response (87.5\% exhibited $>50.000$ reticulocyte/ $\mu \mathrm{L}$ ) (Jain, 1993; Thrall et al., 2004). Despite the peripheral manifestation of normocytic, normochromic, nonregenerative anemia in dogs with stage 3 CKD, no significant alterations were found in their erythropoiesis. Stage 4 of CKD was marked by severe normocytic, normochromic, nonregenerative anemia, erythroid hypoplasia and increased M:E ratio.

No differences were observed in total leukocyte counts between control animals and chronic renal failure patients $(\mathrm{P}=0.09)$ and lymphocyte counts 
were significantly reduced in CKD stage 4 $(\mathrm{P}<0.01)$. None of the dogs exhibited leukocytosis.

A negative correlation was observed between $\mathrm{M}: \mathrm{E}$ ratio and erythroid cells $\left(\mathrm{P}<0.0001 ; \mathrm{r}^{2}=\right.$ 0.94 ) and between $\mathrm{M}: \mathrm{E}$ ratio and the erythrocyte variables (hematocrit, red blood cells and hemoglobin) $\left(\mathrm{P}=0.036 ; \mathrm{r}^{2}=-0.38\right)$.

\section{DISCUSSION}

With the aim of evaluating the feasibility and contribution of sternal bone marrow sampling in dogs with $\mathrm{CKD}$, it was found that this procedure yields good quality samples for cytological analysis and that it provides important information regarding the progression of anemia in this group of dogs.

Retention of active hematopoiesis in the axial skeleton, including the sternebrae, in older patients also makes the sternum an advantageous (Bienzle, 2012) and promises an alternative site for bone marrow sampling in critically ill dogs (Defarges et al., 2013). A recent study regarding pain induced by bone marrow aspiration demonstrated that iliac aspiration seems to elicit more pain and that the sternum is the least invasive site for this procedure (Guillot et al., 2011). Although this was not the main objective of our study, we observed that the majority of the dogs (80.2\%) tolerated sternal bone marrow aspiration with local anesthesia well; the highest level of discomfort was observed during the process of bone marrow suction. This observation leads us to believe that preemptive analgesia could be used to further minimize dogs' sensitivity to this procedure, as seen in a study with humans premedicated with tramadol hydrochloride (Vanhelleputte et al., 2003).

It was also found that erythroid hypoplasia occurred only in terminal CKD patients, and that the bone marrows of dogs with CKD stages 2 and 3 were quantitatively similar to those of elderly dogs. These findings highlight that even though extramedullary factors are important for the onset of anemia (Polzin, 2011, BorinCrivellenti, 2012), CKD stage 4 patients also exhibit associated intramedullary factors. This emphasizes the importance of bone marrow cytological evaluation in these patients and warrants future investigation.
The M:E ratio is an important diagnostic parameter in bone marrow examination together with the overall cellularity and the blood cell counts, it allows an assessment of whether erythropoiesis and/or granulopoiesis are hypoplastic, normal or hyperplastic (Tyler et al, 1999; Thrall et al., 2004). Several M:E ratios have been published in different studies which aimed to find reference values for bone marrow aspiration parameters in adult dogs. The mean value for $\mathrm{M}$ : $\mathrm{E}$ ratio of dogs with stage $4 \mathrm{CKD}$ in the present study (2.41) was significantly higher than the mean value of healthy dogs from the control group (1.24) and from most of previously published studies 1.61, 1.79 and 1.08] (Reutner et al., 1954; Lazarus and Ganaphathy, 1968; Mischke and Busse, 2002, respectively), which emphasizes the lower percentage of erythroid cells in terminal stages of CKD. The high correlation (94\%) between the M:E ratio and the erythroid precursors found in our study is in agreement with previous studies and indicates that the M:E ratio, which is an estimate value, may be used for routine bone marrow examination without the need for a precise blood count.

Although the complete blood count can often reflect the conditions of the central hematopoietic tissue (Thrall et al., 2004), this study demonstrates low correlation between peripheral and central hematological variables in dogs with CKD. Based on these data we emphasize the importance of evaluating the bone marrow in this group of patients, especially in dogs that are already manifesting signs of anemia.

Since anemia is indicated as an important compromising factor for the life quality of dogs with stage 3 and 4 CKD (Polzin, 2011), bone marrow cytological analysis may provide more information on the hematological profile of anemic dogs with CKD and, therefore, allow clinicians to not only choose the most adequate treatment but also monitor the response to therapy. Furthermore, the authors consider that obtaining sternal aspirates of BM under local anesthesia and with an ordinary hypodermic needle also might be possible in critically sick and older dogs with different sizes and various breeds, whenever necessary. 


\section{CONCLUSION}

Bone marrow cytological evaluation using samples obtained from the sternum of dogs with CKD is feasible, well tolerated, and may be a useful tool to complement the hematopoietic evaluation of anemic dogs at different stages of CKD.

\section{ACKNOWLEDGMENTS}

The authors thank Fundação de Amparo à Pesquisa do Estado de São Paulo (FAPESP \#2008/56616-1 and \#2009/52230-4) for scientific and financial support.

\section{REFERENCES}

BIENZLE, D. Collection and interpretation of bone marrow samples. In: DAY, M.J.; KOHN, B. Manual of Canine and Feline Haematology and Transfusion Medicine, 2.ed. Quedgeley, Gloucester: British Small Animal Veterinary Association, 2012. p.21-30.

BORIN-CRIVELLENTI, S. Hematologia e imunologia. In: CRIVELLENTI, L.Z.; BORINCRIVELLENTI, S. Casos de Rotina em Medicina Veterinária de Pequenos Animais. São Paulo: MedVet, 2012. p.210-212.

DEFARGES, A.; ABRAMS-OGG, A.; FOSTER, R.A. et al. Comparison of sternal, iliac, and humeral bone marrow aspiration in Beagle dogs. Vet. Clin. Pathol., v.42, p.170-176, 2013.

FLEISHER, L.A. Preoperative assessment of the patient with cardiac disease. ASA Newsl., v.33, p.77-88, 2005.

GUILLOT, M.; RIALLAND, P.; NADEAU, M.E. et al. Pain induced by a minor medical procedure (bone marrow aspiration) in dogs: comparison of pain scales in a pilot study. J. Vet. Intern. Med., v.25, p.1050-1056, 2011.

IRIS (International Renal Interesting Society) Staging system for chronic kidney disease (CKD). Available at: <http://www.iriskidney.com>. Accessed on: March 08, 2009.

JAIN, N.C. Evaluation of anemias and polycythemias. In: JAIN, N.C. (Ed.) Essentials of veterinary hematology. Philadelphia: Lea \& Febiger, 1993. p.159-168.
LAZARUS, A.E.; GANAPATHY, M.S. Marrow biopsy in canines-technique-cellular pattern in health and disease. Indian. Vet. J., v.45, p.590596, 1968.

MILLER, M.D.; LUNN, K.F. Diagnostic use of cytological examination of bone marrow from dogs with thrombocytopenia: 58 cases (19942004). J. Am. Vet. Med. Assoc., v.231, p.15401544, 2007.

MISCHKE, R.; BUSSE, L. Reference values for the bone marrow aspirates in adult dogs. J. Vet. Med. A., v.49, p.499-502, 2002.

MORITZ, A.; BAUER, N.B.; WEISS, D.J. et al. Evaluation of bone marrow. In: WEISS, D.J.; WARDROP, K.J. (Ed.) Schalm's Veterinary Hematology, 6.ed. Ames: Wiley-Blackwell, 2010. p.1039-1048.

OSGOOD, E.E.; SEAMAN, A.J. The cellular composition of normal bone marrow as obtained by sternal puncture. Physiol. Rev., v.24, p.46-69, 1944.

POLZIN, D.J. Chronic kidney disease in small animals. Vet. Clin. North. Am. Small Anim. Pract., v.41, p.15-30, 2011.

REUTNER, T.F.; WESTON, J.K.; MAXWELL, R.E. et al. Evaluation of peripheral blood and bone marrow in 28 selected mongrel dogs. Fed. Proc., v.13, p.397, 1954.

RILEY, R.S.; HOGAN, T.F.; PAVOT, D.R. et al. A pathologist's perspective on bone marrow aspiration and biopsy: I. Performing a bone marrow examination. J. Clin. Lab. Anal., v.18, p.70-90, 2004.

THRALL, M.A.; WEISER, G.; JAIN, N. Laboratory evaluation of bone marrow. In: THRALL, M.A. (Ed.) Veterinary hematology and clinical chemistry. Philadelphia: Lippincott Williams \& Wilkins, 2004. p.149-178.

TYLER, R.D.; COWELL, R.L.; MEINKOTH, J.H. Bone marrow. In: COWELL, R.L.; TYLER, R.D.; MEINKOTH, J.H. (Ed.) Diagnostic Cytology and Haematology of the Dog and Cat. St. Louis: Mosby, 1999. p.284-304.

VANHELLEPUTTE, P.; NIJS, K.; DELFORGE, M. et al. Pain during bone marrow aspiration: prevalence and prevention. J. Pain Symptom. Manage., v.26, p.860-866, 2003. 